Article

\title{
The Composition and Stability of Clay-Associated Organic Matter along a Soil Profile
}

\author{
Chunmei Chen ${ }^{1, *}$, Peter Leinweber ${ }^{2}$, Kai-Uwe Eckhardt ${ }^{2}$ and Donald L. Sparks ${ }^{1}$ \\ 1 Delaware Environmental Institute, Department of Plant and Soil Science, University of Delaware, \\ Newark, DE 19716, USA; dlsparks@udel.edu \\ 2 Soil Science, University of Rostock, Justus-von-Liebig-Weg 6, 18051 Rostock, Germany; \\ peter.leinweber@uni-rostock.de (P.L.); kai-uwe.eckhardt@uni-rostock.de (K.-U.E.) \\ * Correspondence: cmchen@udel.edu; Tel.: +1-302-983-3299
}

Received: 19 February 2018; Accepted: 13 March 2018; Published: 14 March 2018

\begin{abstract}
Organic carbon in subsoil generally has longer turnover times than that in surface soil, but little is known about how the stability of the specific organic compound classes changes with soil depth. The objective of this study was to analyze the composition and thermal stability of clay-associated organic matter (OM) at varying soil depths in the summit and footslope of a pasture hillslope using C X-ray absorption near edge structure (XANES) and pyrolysis-field ionization mass spectrometry (Py-FIMS). C XANES showed aromatic $C$ was relatively enriched in the subsoil, relative to the surface soil. Py-FIMS demonstrated a relative enrichment of phenols/lignin monomers and alkylaromatics with increasing profile depth in the summit soil, and to a greater extent in the footslope soil, followed by a decreasing abundance of sterols. In surface soil, the thermostability of clay-associated OM increases in the order: carbohydrates and $\mathrm{N}$ compounds < phenols/lignin monomers < lignin dimers and alkylaromatics, suggesting the intrinsic chemical nature of $\mathrm{OM}$ as a major driver for $\mathrm{OM}$ persistent in surface soil. The thermal stability of clay-associated carbohydrates, $\mathrm{N}$ compounds, and phenols/lignin monomers increased with profile depth, likely due to stronger organic-organic/organic-mineral binding. In subsoil, the thermal stability of clay-associated carbohydrates and $\mathrm{N}$ compounds can be as high as that of alkylaromatic and lignin dimers, implying that persistent subsoil OM could be composed of organic compound classes, like carbohydrates, that were traditionally considered as biochemically labile compounds. In contrast, the thermally-stable compound classes, like lignin dimers and alkylaromatics, showed no changes in the thermal stability with soil depth. This study suggests that stability of the more labile OM compounds may be more strongly influenced by the change in environmental conditions, relative to the more stable forms.
\end{abstract}

Keywords: organic matter chemistry; thermal stability; soil depth; Py-FIMS; XANES

\section{Introduction}

The ability of SOM to persist over time is a key determinant in understanding carbon turnover on both local and global scales [1]. The mechanisms controlling the persistence of SOM are still under debate [1,2]. SOM composition was considered to be one of the main factors determining organic matter $(\mathrm{OM})$ turnover for decades, due to the presumed recalcitrance of certain molecules. However, the importance of molecular composition as a control for SOM persistence has been challenged $[1,3,4]$, and it is now recognized that the chemical recalcitrance alone cannot fully explain the long-term persistence of SOM [2]. Instead, organo-mineral association is acknowledged by many researchers as the main driver for OM persistence [1,2,5]. This mechanism contributes to the long residence time of even chemically labile and quickly decomposable organic compounds, such as sugars [1]. However, the high diversity of soils and ecosystems make it difficult to predict the impacts of biogeochemical regulators on organic carbon (OC) storage. The relative importance of all the mechanisms may differ 
depending on specific environmental conditions, soil features, and vegetation $[1,6,7]$. Understanding of the chemistry and stability of SOM at different soil depths is needed to understand the controlling factors of SOM persistence in dynamic landscapes.

Subsoils store $30-60 \%$ of global soil organic carbon (SOC), but the storage mechanisms and degradation processes are still poorly understood [8]. Recently, there is an increasing interest in subsoil OC storage and turnover to evaluate $\mathrm{SOC}$ behavior in deeper soil regions as a potential $\mathrm{CO}_{2}$ source as a result of climate or management changes [8]. In contrast to topsoils, subsoils are characterized by low $C$ content and high radiocarbon ages [5,9-11], indicating high $C$ stability. However, little is known about the mechanisms controlling SOC turnover in subsoils. In the context of climate change and SOM as potential sink for atmospheric $\mathrm{CO}_{2}$, it is important to understand what leads to sequestration of large amounts of old $\mathrm{C}$ below the A horizon. There is some evidence that subsoil $\mathrm{OM}$ compounds are highly processed residues of microbial degradation and are recalcitrant for further microbial degradation [12-14]. However, recent studies found large amounts of easily-degradable SOM components in subsoils, like simple carbohydrates or amino sugars [15-17], which can persist over a long time [18]. The persistence of such easily degradable compounds might be due their spatial inaccessibility to microorganisms $[17,19]$. Next to the composition of $C$ substrates, temperature, moisture, and soil texture, key factors controlling SOM decomposition rates on a regional scale, also vary with depth in a soil profile [20], as do microbial and fungal activities [21]. Environmental conditions, such as low temperature or low $\mathrm{pH}$ may limit subsoil OM mineralization [22-24]. Another proposed mechanism for the greater stability of subsoil OM is increased association of OM with metal oxyhydroxides and clay minerals $[1,9,25,26]$, which can reduce the accessibility of SOM to microbial decomposers. Subsoil horizons lose more carbon upon HF treatment than topsoil horizon (Rumpel and Kögel-Knabner [9] and references therein), suggesting a higher contribution of mineral-associated $\mathrm{C}$ (the $\mathrm{C}$ lost upon demineralization of soil by HF) in subsoil horizons. In addition, it was implied that SOM in subsoil horizons becomes older, when a greater proportion of SOM is associated with the mineral phase [27]. However, there is surprisingly little information on the chemistry and stability of mineral-associated SOM in subsurface horizons or how subsurface SOM is affected by organo-mineral associations. A better understanding of the characteristics of SOM in subsurface horizon is needed to improve modeling of organic matter turnover and storage on a landscape scale [28].

Grasslands are one of the most widespread vegetation types world-wide and play a crucial role in the global terrestrial C cycle $[29,30]$. To date, a few studies have examined OM composition of the whole soils in the grassland subsurface [31,32], but the composition of mineral-associated $\mathrm{OM}$ in grassland subsoils remain elusive. In addition, soil processes (such as drainage and aeration) may have a strong influence on the vertical distribution of SOM composition [33]. For example, lignin quantified with chemolysis, $\mathrm{CuO}$ oxidation and GC-MS analysis were shown to decrease with profile depth in well-drained soils [31,33]. However, under poorly-drained conditions, lignin preferentially accumulated in subsoils [34], likely due to a slower decomposition rate in $\mathrm{O}_{2}$-limited environments [35,36]. Therefore, low-lying sites may display different vertical distribution patterns of SOM composition, compared with well-drained landscape positions. Furthermore, little has been conducted to investigate the influence of soil depth on the stability of individual organic compound classes associated with soil minerals in grasslands. Such information is needed to better understand the biogeochemical characteristics of persistent SOM in the natural environment.

In this study, we hypothesize that (1) the vertical distribution of SOM composition differs between well- and poorly-drained landscape positions; and (2) the stability of the individual OM compound classes are not equally affected by soil depth, with the labile compound classes more sensitive to depth changes. To test these hypotheses, we sampled the summit (well-drained) and footslope (relatively poorly-drained) of a pasture hillslope at three soil depths $(0-15,15-25,25-35 \mathrm{~cm})$, respectively. The objectives of this study were (1) to employ C XANES to assess bulk functional groups of SOM in soil clay fractions; and (2) to apply Py-FIMS to evaluate OM structure in more detail, as well as to measure the thermal stability of OM compound classes in soil clay fractions, since a majority of SOM is associated with clay minerals $[37,38]$. 


\section{Materials and Methods}

\subsection{Field Sampling}

Our field site is located within the long-term 725-ha research watershed upstream of the Stroud Water Research Center (SWRC) in southeastern PA (39 $53^{\prime}$ N, $75^{\circ} 47^{\prime}$ E) (Figure S1). The 3rd-order watershed forms the headwaters of the White Clay Creek and is an intensive study site for the established Christina River Basin Critical Zone Observatory. Approximately $52 \%$ of the watershed area is in pasture [39]. Since pasture was established on the land in 1950s, the studied hillslope has been relatively stabilized and soil redistribution on the hillslope might be very minimal since then. The watershed is underlain by highly metamorphosed sedimentary rocks containing gneisses, schists, quartzites, and marbles [40]. The soils are primarily Typic Hapludults [39]. We targeted a pasture hillslope with a relative elevation and distance difference of $\sim 7 \mathrm{~m}$ and $\sim 60 \mathrm{~m}$, respectively, and slopes up to $14 \%$ (Supplementary Materials, Figure S1). Soils from this hillslope shared similar clay mineralogy and the dominant soil clay minerals are hydroxyl-interlayered vermiculite, illite and kaolinite [38]. The vegetation (grass) is relatively uniform along the hillslope. The footslope soils were slowly and poorly drained after precipitation, whereas the summit and backslope soils were well drained. Therefore the color of the footslope soils was more grayish than that of the upslope soils (Table S1). Soil samples were collected from the summit and footslope at soil depths of 0-15 (A horizon), 15-25 (B horizon) and 25-35 cm (B horizon), respectively. Three soil samples were taken per location for each depth increment, air-dried and sieved through a 2-mm sieve before clay separation and further analysis.

\subsection{Clay Fraction Separation}

The clay fraction separation was performed according to Amelung et al. [41]. Briefly, $30 \mathrm{~g}$ of soil were ultrasonically treated with an energy input of $60 \mathrm{~J} \mathrm{~mL}^{-1}$ using a probe type sonicator at a soil/water ratio of 1:5 $(w / v)$. The coarse sand fraction $(>250 \mu \mathrm{m})$, which contains a significant amount of particulate organic matter, was removed by wet sieving. To completely disperse the remaining suspension, ultrasonication was again applied with an energy input of $440 \mathrm{~J} \mathrm{~mL}^{-1}$ at a soil/water ratio of 1:10 $(w / v)$. The sand fraction $(>53 \mu \mathrm{m})$, which also has a considerable amount of particulate organic matter, was removed by wet sieving. The clay-sized fraction $(<2 \mu \mathrm{m})$ was separated from the silt- and sand-sized separates by repeated centrifugation. The clay suspensions were centrifuged and the solids were freeze-dried for further analysis. The STXM analysis suggests that OM was mainly associated with soil minerals in the clay fractions and there was no independent particulate OM phase [38].

\subsection{Soil Properties}

The crystalline and poorly crystalline Fe oxides (Fed) of the whole soils were estimated using the dithionite-citrate-bicarbonate (DCB) method [42]. The poorly-crystalline Fe oxides (Feo) of the whole soils were determined using a $0.275 \mathrm{M}$ ammonium oxalate extraction in the dark at $\mathrm{pH} 3.25$ [43]. $\mathrm{C}$ and $\mathrm{N}$ content of the whole soils and clay fractions was analyzed by dry combustion with a vario cube CNS analyzer (Elementar, Langenselbold, Germany). Soil mineral surface area (SSA) of the whole soils and clay fractions was measured after OM removal. OM was removed by oxidation with a $10 \%$ $\mathrm{H}_{2} \mathrm{O}_{2}$ solution at room temperature. We are aware that incomplete $\mathrm{OM}$ removal could underestimate the mineral surface area, since $\mathrm{H}_{2} \mathrm{O}_{2}$ removed $85-90 \%$ OM in the soils (data not shown). The SSA was determined by the $\mathrm{N}_{2}$-adsorption BET method using a Micromeritics TriStar 3000 surface area and porosity analyzer (Micromeritics, Norcross, GA, USA). The SSA was derived from the adsorption isotherm of $\mathrm{N} 2$ at $77 \mathrm{~K}$, and the BET equation was applied to the data in the P/Po range of 0.05 to 0.30 (11 point BET) [44].

\subsection{Carbon K-Edge X-ray Absorption Near Edge Structure Spectroscopy}

C XANES spectroscopy was applied to determine bulk functional groups of SOM in the clay fractions. For the C XANES analysis, soil clay fractions were slurried in DI water, deposited onto 
$\mathrm{Au}$-coated $\mathrm{Si}$ wafers, and air-dried at room temperature. The wafers were then affixed to sample holders using double-sided carbon tape for insertion into the absorption chamber. Carbon K-edge XANES spectra were collected using the Spherical Grating Monochromator (SGM) beamline 11ID-1 at the Canadian Light Source (CLS, Saskatoon, SK, Canada), which delivers 1011 photons S - 1 with a resolving power $(E / \Delta E)$ greater than 104 [45]. C (1s) XANES spectra of the samples were collected using a photodiode and recorded from 270 to $320 \mathrm{eV}$ in steps of $0.1 \mathrm{eV}$ using a dwell time of $500 \mathrm{~ms}$. The exit slit gap was $25 \mu \mathrm{m}$. Background measurements were collected by measuring an empty gold-coated silicon wafer. A Ti filter was used in the beamline to reduce the effects of 2nd oxygen in the pre-edge region. In order to minimize beam damage to organic matter, we collected only one spectrum from one spot. At least four to six spectra were collected from each sample and averaged. The XANES spectra for samples from a depth of 25-35 cm were not successfully collected due to much lower $C$ content. The $C$ XANES spectra were energy calibrated using the $1 \mathrm{~s} \rightarrow \pi^{*} \mathrm{C}=\mathrm{O}$ transition of glutaric acid at $288.6 \mathrm{eV}$. Resonances corresponding to $\mathrm{C}$ types have been identified as: aromatic $\mathrm{C}$ at $285.5 \mathrm{eV}$, aliphatic $\mathrm{C}$ at $287.3 \mathrm{eV}$, carboxylic $\mathrm{C}$ at $288.6 \mathrm{eV}$, and O-alkyl C at $289.7 \mathrm{eV}$ [38,46-48].

Data processing was performed using aXis 2000 (McMaster University, Hamilton, ON, Canada). First, we calculated the difference between the sample spectrum and a background spectrum from a gold-coated silicon wafer by adjusting the gain and offset of the sample spectrum. The spectrum difference was then normalized to the incident flux (I0) to account for attenuation of the photo beam by $C$ on the optical component. We averaged 4-6 scans for each sample and corrected background with a linear regression fit through the pre-edge region, followed by normalization to an edge step of one.

\subsection{Pyrolysis-Field Ionization Mass Spectrometry}

Pyrolysis-field ionization mass spectrometry was performed to determine the relative molecular composition and the thermal stability of SOM in whole soil samples and their clay fractions. Five milligrams of each air-dried, ground, and homogenized sample (three repetitions) were degraded by pyrolysis in the ion source (emitter: $4.7 \mathrm{kV}$, counter electrode $-5.5 \mathrm{kV}$ ) of a double-focusing Finnigan MAT 95 mass spectrometer (Finnigan MAT GmbH, Bremen, Germany). The samples were heated in a vacuum of $10^{-4} \mathrm{~Pa}$ from $50{ }^{\circ} \mathrm{C}$ to $700{ }^{\circ} \mathrm{C}$, in temperature steps of $10^{\circ} \mathrm{C}$ over a period of $18 \mathrm{~min}$. Between magnetic scans the emitter was flash heated to avoid residues of pyrolysis products. 65 spectra were recorded for the mass range 15 to $900 \mathrm{~m} / z$. Ion intensities were referred to $1 \mathrm{mg}$ of the sample. Volatile matter was calculated as mass loss in percentage of sample weight. Interpretation of marker signals $(\mathrm{m} / \mathrm{z})$, which are assigned to relevant compound classes, was described by Leinweber et al. $[49,50]$ and also included in the Supplementary Materials. The ion intensities of the marker signals were attributed to the following compound classes: (1) CHYDR-carbohydrates; (2) PHLM-phenols and lignin monomers; (3) LDIM-lignin dimers; (4) LIPID-lipids, alkanes, alkenes, and alkyl monoesters; (5) ALKYL-alkylaromatics; (6) NCOMP-mainly heterocyclic N-containing compounds; (7) STEROL-sterols; (8) PEPTI-peptides; (9) SUBER-suberin; and (10) FATTY-fatty acids. The average ion intensities for each class of compound were plotted against the pyrolysis temperature, giving characteristic thermograms, which gives an indication of the thermal energy required for volatilization of individual biomarkers of SOM. Close relationships between microbial decomposition and thermal stability in Py-FIMS [42] were reflected by a separation of Py-FIMS thermograms into thermally labile (faster degradable, $<400{ }^{\circ} \mathrm{C}$ ) and stable (slower degradable, $>400{ }^{\circ} \mathrm{C}$ ) proportions [51]. Therefore, these criteria will be used to discuss SOM stability.

\subsection{Data Analysis}

All results are presented as arithmetic means of three replicates. The statistical analyses were carried out using the SPSS 20.0 software package (IBM Corp., Armonk, NY, USA). To compare the fractions, one-way analysis of variance (ANOVA) and post-hoc Scheffé tests were performed. 


\section{Results}

\subsection{General Soil Properties}

Relative to the bulk soils, the soil clay fractions had higher $\mathrm{C}$ and $\mathrm{N}$ concentrations and mineral surface area (SSA), but lower $\mathrm{C} / \mathrm{N}$ ratio and $\mathrm{C}$ loading (normalized $\mathrm{C}$ concentration by mineral surface area) for all the samples (Table 1). $\mathrm{C}$ and $\mathrm{N}$ concentration, $\mathrm{C} / \mathrm{N}$ ratio, and $\mathrm{C}$ loading generally decreased with soil depth at both the summit and footslope locations, whereas mineral surface area showed slight changes along the soil profile (Table 1).

\subsection{K-Edge X-ray Absorption Near Edge Structure (XANES) Spectroscopy}

In general, for all the samples C K-edge XANES spectra exhibited major features for aromatic $(\sim 285.5 \mathrm{eV})$ and carboxylic C ( 288.6 eV), whereas aliphatic $(\sim 287.3 \mathrm{eV})$ and O-alkyl C $(\sim 289.7 \mathrm{eV})$ were of minor fractions (Figure 1). The aromatic $C$ differed in relative intensity among the samples, while the relative intensity of carboxylic, aliphatic, and O-alkyl C peaks showed similarity among the samples (Figure 1). The relative intensity of the aromatic C peak was greater at a soil depth of $15-25 \mathrm{~cm}$ than at a soil depth of $0-15 \mathrm{~cm}$ in the summit profile, and, to a greater extent in the footslope profile (Figure 2).

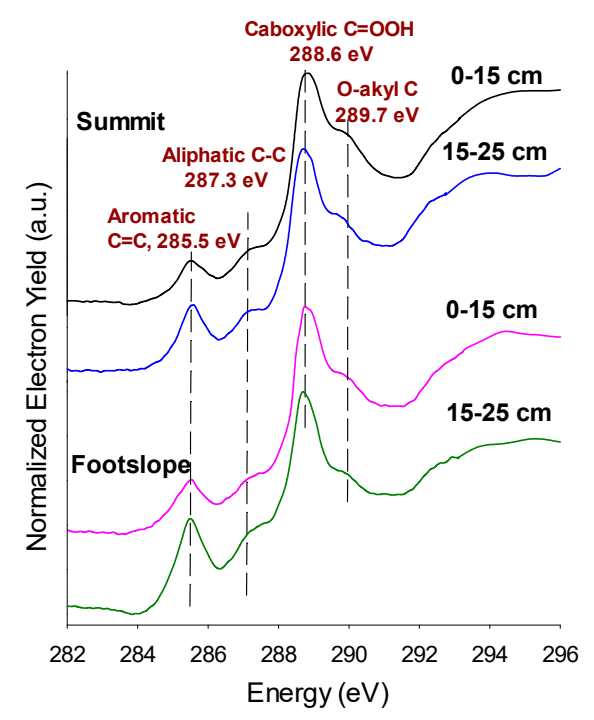

Figure 1. Carbon K-edge XANES spectra of soil clay fractions from the hillslope transect at soil depths of $0-15 \mathrm{~cm} \mathrm{(a)} \mathrm{and} \mathrm{15-25} \mathrm{cm} \mathrm{(b).} \mathrm{Carbon} \mathrm{features} \mathrm{are} \mathrm{assigned} \mathrm{to} \mathrm{aromatic} \mathrm{C}$ at $285.5 \mathrm{eV}$, aliphatic $\mathrm{C}$ at $287.3 \mathrm{eV}$, carboxylic C at $288.6 \mathrm{eV}$, and O-alkyl C at $289.7 \mathrm{eV}$.

\subsection{Pyrolysis-Field Ionization Mass Spectrometry}

\subsubsection{Soil Organic Matter Compound Classes}

Assignment of marker signals to important compound classes of SOM revealed that SOM in these pasture soils primarily contained the following compound classes (in order of relative abundance): alkylaromatics $>$ phenols + lignin monomers $>$ carbohydrates $>$ amides (Table 2). The proportions of lignin dimers and fatty acids were small (Table 2). At both the summit and footslope locations, a decrease in the relative percentages of lignin dimers and sterols was observed with increasing soil depth, whereas the proportions of alkylaromatics and phenols/lignin monomers significantly increased with increasing soil depth (Table 2). Surface soil OM composition was similar between the summit and footlsope location. However, footslope soil displayed a greater degree of increase in the proportions of alkylaromatics and phenols/lignin monomers with increasing soil depth, compared to the summit soil profile (Table 2). 
Table 1. $\mathrm{C}$ and $\mathrm{N}$ concentrations, atomic $\mathrm{C} / \mathrm{N}$ ratio, mineral surface area (SSA), and $\mathrm{C}$ loading (normalized $\mathrm{C}$ content by mineral surface area) in whole soils and clay fractions.

\begin{tabular}{|c|c|c|c|c|c|c|c|c|c|c|c|}
\hline \multirow{2}{*}{$\begin{array}{l}\text { Landscape } \\
\text { Location }\end{array}$} & \multirow{2}{*}{$\begin{array}{l}\text { Soil Depth } \\
\text { (cm) }\end{array}$} & \multicolumn{2}{|c|}{$\mathrm{C}$ concentration $\left(\mathrm{mg} \mathrm{g}^{-1}\right)$} & \multicolumn{2}{|c|}{$\mathrm{N}$ Concentration $\left(\mathrm{mg} \mathrm{g}^{-1}\right)$} & \multicolumn{2}{|c|}{ C/N Ratio } & \multicolumn{2}{|c|}{$\operatorname{SSA}\left(\mathrm{m}^{2} \mathrm{~g}^{-1}\right)$} & \multicolumn{2}{|c|}{ C Loadings $\left(\mathrm{mg} \mathrm{C} \mathrm{m}^{-2}\right)$} \\
\hline & & Whole Soil & Clay Fraction & Whole Soil & Clay Fraction & Whole Soil & Clay Fraction & Whole Soil & Clay Fraction & Whole Soil & Clay Fraction \\
\hline \multirow{3}{*}{ Summit } & $0-15$ & $30.6^{a, *}$ & $72.6^{\mathrm{a}}$ & $3.3^{\mathrm{a}}$ & $9.3^{\mathrm{a}}$ & $10.8^{\mathrm{b}}$ & $7.8^{\mathrm{a}}$ & $14.5^{\mathrm{b}}$ & $65.7^{\mathrm{a}}$ & $2.1^{\mathrm{a}}$ & $1.1^{\mathrm{a}}$ \\
\hline & $15-25$ & $17.5^{\mathrm{c}}$ & $49.1^{\mathrm{c}}$ & $2.0^{\mathrm{c}}$ & $6.4^{c}$ & $10.2^{\mathrm{c}}$ & $7.7^{\mathrm{a}}$ & $15.4^{\mathrm{a}}$ & $66.2^{\mathrm{a}}$ & $1.1^{\mathrm{b}}$ & $0.7^{b}$ \\
\hline & $25-35$ & $6.6^{\mathrm{e}}$ & $18.1^{\mathrm{e}}$ & $0.8^{\mathrm{d}}$ & $2.5^{\mathrm{d}}$ & $9.6^{\mathrm{d}}$ & $7.2^{c}$ & $14.1^{\mathrm{b}}$ & $65.4^{\mathrm{a}}$ & $0.5^{c}$ & $0.3^{c}$ \\
\hline \multirow{3}{*}{ Footslope } & $0-15$ & $27.9^{b}$ & $68.9^{b}$ & $2.9^{\mathrm{b}}$ & $8.4^{\mathrm{b}}$ & $11.5^{\mathrm{a}}$ & $8.2^{\mathrm{a}}$ & $12.2^{\mathrm{C}}$ & $58.2^{b}$ & $2.2^{\mathrm{a}}$ & $1.2^{\mathrm{a}}$ \\
\hline & $15-25$ & $15.9^{\mathrm{d}}$ & $45.3^{d}$ & $1.8^{\mathrm{c}}$ & $6.0^{c}$ & $10.3^{c}$ & $7.6^{\mathrm{a}, \mathrm{b}}$ & $11.6^{\mathrm{c}}$ & $57.4^{\mathrm{b}, \mathrm{c}}$ & $1.4^{\mathrm{b}}$ & $0.8^{\mathrm{b}}$ \\
\hline & $25-35$ & $5.5^{\mathrm{f}}$ & $15.8^{\mathrm{f}}$ & $0.7^{\mathrm{d}}$ & $2.1^{\mathrm{d}}$ & $8.7^{\mathrm{d}, \mathrm{e}}$ & $7.5^{\mathrm{b}}$ & $11.5^{\mathrm{c}}$ & $55.8^{\mathrm{c}}$ & $0.4^{\mathrm{c}}$ & $0.3^{c}$ \\
\hline
\end{tabular}

${ }^{*}$ values are the means of three replicates, and values followed by the different letters $(\mathrm{a}, \mathrm{b}, \mathrm{c}, \mathrm{d}, \mathrm{e}, \mathrm{f})$ within any given column are significantly different at $p<0.05$.

Table 2. Proportions of compound classes from pyrolysis-field ionization mass spectrometry of the summit and footslope soil clay fractions from soil depths of 0-15, $15-25$ and $25-35 \mathrm{~cm}$ (\% of total ion intensity).

\begin{tabular}{|c|c|c|c|c|c|c|c|c|c|c|}
\hline \multirow{2}{*}{ Landscape Location } & \multirow{2}{*}{ Soil Depth (cm) } & CHYDR & PHLM & LDIM & LIPID & ALKYL & NCOMP & STEROL & PEPTI & FATTY \\
\hline & & \multicolumn{9}{|c|}{$\%$ TII } \\
\hline \multirow{3}{*}{ Summit } & $0-15$ & $7.9^{a, *}$ & $8.9^{\mathrm{d}}$ & $2.4^{\mathrm{a}}$ & $4.3^{b}$ & $9.1^{\mathrm{e}}$ & $4.3^{b, c}$ & $1.7^{\mathrm{a}}$ & $7.5^{\mathrm{a}}$ & $0.9^{\mathrm{a}, \mathrm{b}}$ \\
\hline & $15-25$ & $8.6^{\mathrm{a}}$ & $11.0^{\mathrm{c}}$ & $1.7^{\mathrm{b}}$ & $5.5^{\mathrm{a}}$ & $12.1^{\mathrm{d}}$ & $5.2^{\mathrm{a}}$ & $1.0^{\mathrm{b}}$ & $7.1^{\mathrm{a}}$ & $0.7^{\mathrm{b}}$ \\
\hline & $25-35$ & $5.9^{c}$ & $13.0^{\mathrm{b}}$ & $1.7^{\mathrm{b}}$ & $5.8^{\mathrm{a}}$ & $15.7^{b}$ & $4.7^{\mathrm{a}}$ & $0.4^{\mathrm{c}}$ & $6.1^{b}$ & $1.1^{\mathrm{a}}$ \\
\hline \multirow{3}{*}{ Footslope } & $0-15$ & $7.1^{b}$ & $8.7^{\mathrm{d}}$ & $2.6^{a}$ & $5.2^{\mathrm{a}}$ & $9.9 \mathrm{e}$ & $3.7^{\mathrm{c}}$ & $2.2^{a}$ & $6.3^{b}$ & $1.2^{\mathrm{a}}$ \\
\hline & $15-25$ & $7.0^{\mathrm{b}}$ & $13.3^{b}$ & $1.5^{\mathrm{b}}$ & $5.4^{\mathrm{a}}$ & $14.1^{\mathrm{c}}$ & $3.9^{c}$ & $1.2^{b}$ & $6.0^{b}$ & $1.2^{\mathrm{a}}$ \\
\hline & $25-35$ & $7.8^{\mathrm{a}}$ & $21.0^{\mathrm{a}}$ & $0.3^{c}$ & $3.9^{b}$ & $22.9^{a}$ & $5.6^{\mathrm{a}}$ & $0.0^{\mathrm{d}}$ & $7.5^{\mathrm{a}}$ & $0.1^{\mathrm{c}}$ \\
\hline
\end{tabular}

CHYDR = carbohydrates; PHLM = phenols + lignin monomers; LDIM = lignin dimers; LIPID = lipids, alkanes, alkenes, and n-alkyl esters; ALKYL = alkylaromatics; NCOMP = heterocyclic nitrogen and nitriles; STEROL = sterols; PEPTI = amides (amino acids, peptides and amino sugars); FATTY = fatty acids. ${ }^{*}$ values are the means of three replicates, and values followed by the different letters $(\mathrm{a}, \mathrm{b}, \mathrm{c}, \mathrm{d})$ within any given column are significantly different at $p<0.05$. 

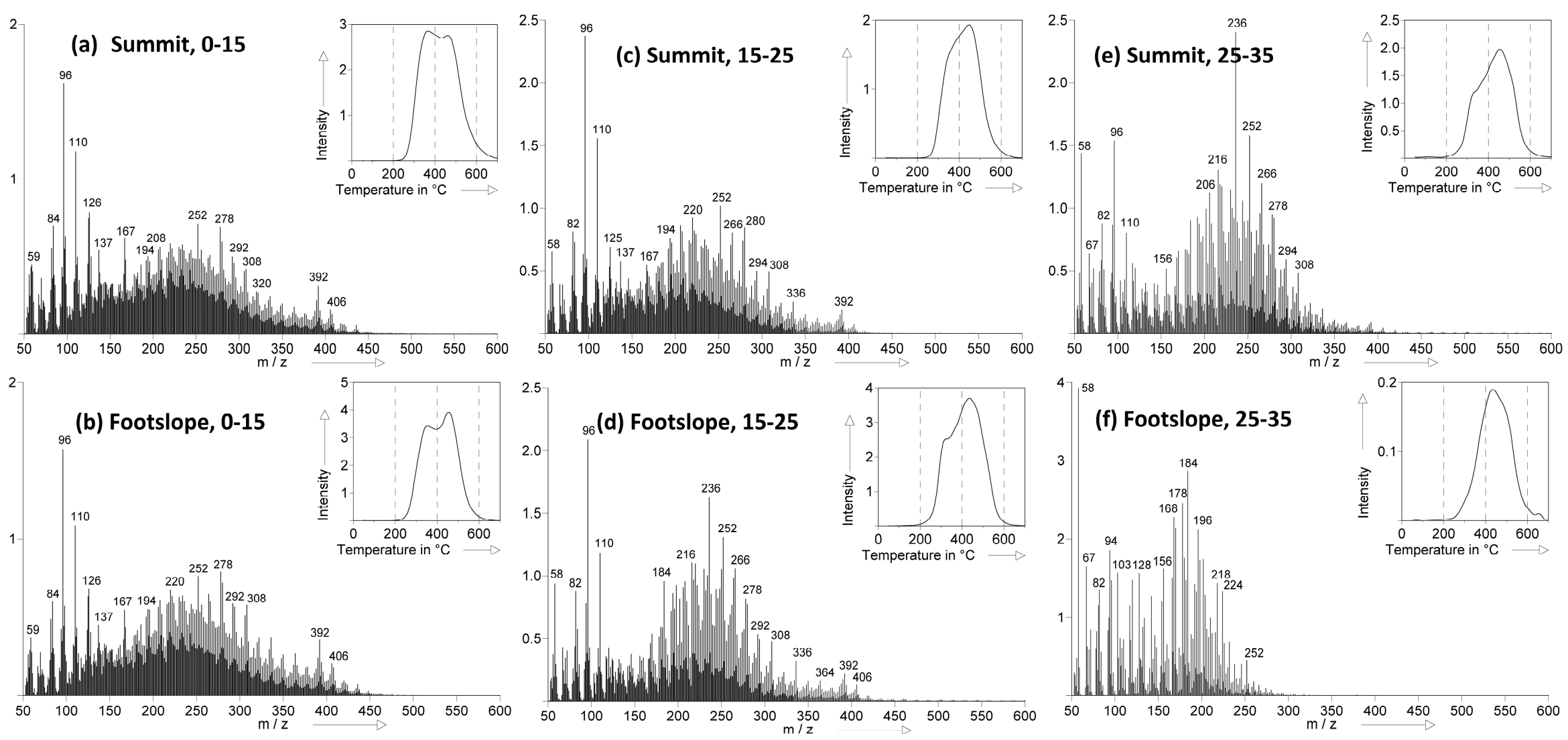

Figure 2. Summed and averaged pyrolysis-field ionization mass spectra and thermograms of total ion intensity (TII, inset) of the summit and footslope soil clay fractions from soil depths of $0-15,15-25$, and $25-35 \mathrm{~cm}$. 


\subsubsection{SOM Thermal Stability}

The TII thermograms demonstrated that SOM thermal stability increased with profile depth (Figure 2). The TII thermogram (see upper right inserts) for footslope soils at a depth $25-35 \mathrm{~cm}$ was of a monomodal shape, whereas the thermograms for the other soils were of biomodal shape, which can be divided into a thermally labile $\left(<400{ }^{\circ} \mathrm{C}\right)$ and stable $\left(>40{ }^{\circ} \mathrm{C}\right)$ section (Figure 2$)$. As soil depth increases, the low-temperature $\left(<400^{\circ} \mathrm{C}\right)$ volatilization peak decreased, followed by an increase in the relative abundance of high-temperature volatilization peaks $\left(>400{ }^{\circ} \mathrm{C}\right)$. In addition, for the footslope soil at a depth of $25-35 \mathrm{~cm}$, the low-temperature volatilization peak disappeared and only the high-temperature volatilization peak is observed.

Thermal volatilization curves of individual compound classes showed that the thermal stability of carbohydrates, $\mathrm{N}$ compounds and phenols/lignin monomers increased with soil depth, whereas the thermal stability of lignin dimers and alkylaromatics showed no variation with soil depth at both the summit and footslope locations (Figure 3). At soil depths of $0-15 \mathrm{~cm}$, the thermograms of clay-associated OM displayed that: (1) the majority of carbohydrates, heterocyclic nitrogen and nitriles, and amides were volatile at lower temperature $\left(330-350{ }^{\circ} \mathrm{C}\right.$ ) (Figure 3a-c); (2) lignin dimers and alkylaromatics showed the most intensive volatilization at high pyrolysis temperature $\left(430-470{ }^{\circ} \mathrm{C}\right)$ (Figure 3e,f); and (3) the volatilization curves of phenols/lignin monomers showed one major peak at $\sim 350^{\circ} \mathrm{C}$ and a second peak at $\sim 470^{\circ} \mathrm{C}$ at a soil depth of $0-15 \mathrm{~cm}$ (Figure $3 \mathrm{~d}$ ). These results indicate that the thermal stability of clay-associated organic compound classes in surface soils decreased in the order: lignin dimers and alkylaromatics $>$ phenols/lignin monomers $>$ carbohydrates, heterocyclic nitrogen and nitriles, and amides. In the surface soils, even clay-associated SOM contained a large faction of labile compound classes like carbohydrates and N-containing compounds. As soil depth increased from $0-15$ to $15-25 \mathrm{~cm}$, the volatilization temperature remained relatively unchanged for heterocyclic nitrogen and nitriles in the summit soil, whereas a shift in peak temperature from 340 to $420{ }^{\circ} \mathrm{C}$ was observed in the footslope soil (Figure 3b). As soil depth increased to $25-35 \mathrm{~cm}$, the volatilization maxima of carbohydrates, heterocyclic nitrogen and nitriles, and amides shifted toward higher temperatures for both the summit and footslope soils (Figure 3a-c), indicating more thermal energy was required for these compounds to be released from the soils. The peak temperature for carbohydrates shifted from 330 to 370 and $410{ }^{\circ} \mathrm{C}$ in the summit and footslope soils, respectively. The volatilization peaks for amides increased from $340-350$ to 420 and $440{ }^{\circ} \mathrm{C}$ in the summit and footslope soils, respectively. Heterocyclic nitrogen and nitriles made the greatest shifts, and the volatilization maxima for heterocyclic nitrogen and nitriles increased from 340 to 430 and $470{ }^{\circ} \mathrm{C}$ in the summit and footslope soils, respectively. In addition, as soil depth increases, the low-temperature peak for phenols and lignin monomers was strongly reduced or disappeared, followed by an increased high-temperature volatilization peak (Figure 3d). In contrast, the volatilization curves of lignin dimers and alkylaromatics did not vary dramatically with soil depth (Figure 3e,f). 

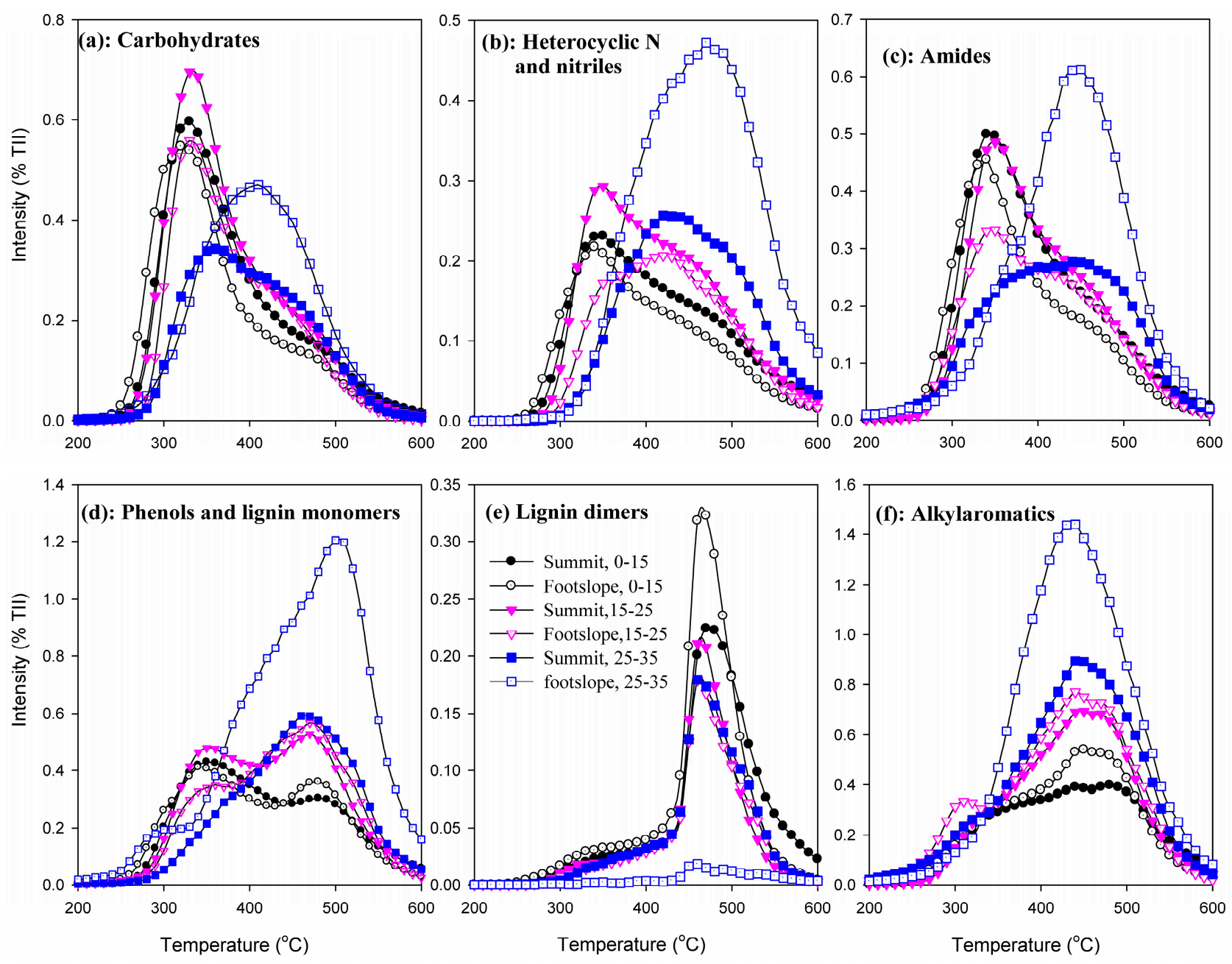

Figure 3. Pyrolysis thermograms of (a) carbohydrates, (b) heterocyclic nitrogen and nitriles, (c) amides, (d) phenols and lignin monomers, (e) lignin dimers, and (f) alkylaromatics for the summit and footslope soil clay fractions at soil depths of $0-15,15-25$, and $25-35 \mathrm{~cm}$. Peaks at higher temperatures indicate higher thermal stability. 


\section{Discussion}

\subsection{Variation in Organic Matter Chemistry with Depth}

The results of this study are consistent with previous findings [31-33,52-54], who demonstrated that SOM chemistry shows marked changes with depth. Overall, subsurface SOM is relatively enriched in alkylaromatics, phenols/lignin monomers, accompanied by a decreasing proportion of sterols with increasing soil depth in both the summit and footslope locations. The enrichment of aromatic $C$ in the subsurface as shown by $C$ XANES could be attributed to the increased proportions of both alkylaromatics and phenols + lignin monomers, which is consistent with previous findings of Ussiri and Johnson [52] and Djukic et al. [54], who observed increases in aromatic C with soil depth using NMR and FTIR techniques. The decreasing abundance of sterols with soil depth is due to the lower input of plant materials, since sterols originating from octacosanol/nonacosanol at, $m / z$ 392/406 (Figure 3) [55,56], are of a plant origin. The relative proportions of alkylaromatics in the summit soil are comparable to those reported for the well-drained cultivated soils by Py-FIMS analysis $[57,58]$. The thermal stability of alkylaromatics showed no variation with soil depth and, thus, the greater proportion of alkylaromatics in subsoils is not due to the increased protection with soil depth. A higher proportion of alkylaromatics in conjunction with higher phenols/lignin monomers to lignin dimers ratios in the subsurface suggest a more decomposed character of the subsoil OM. This is further supported by decreasing $\mathrm{C} / \mathrm{N}$ ratios with soil depth, reflecting the advanced degradation of organic residues [59,60]. It appears plausible that surface SOM is comprised of younger materials, while subsurface SOM compounds are relatively more degraded and transformed, due to the input of recent organic debris close to the surface.

An increasing proportion of phenols/lignin monomers with soil depth was observed in both locations. Previous studies, which have examined the distribution of lignin-derived phenols with soil depth by chemolysis, $\mathrm{CuO}$ oxidation and GC-MS analysis, have reported inconsistent findings $[31,33,34,53,60]$. One should be careful when interpreting lignin phenol data, since lignin phenols can be measured in a variety of ways, each yielding very different absolute values. Although the lignin-derived phenols and phenols from other sources have different behavior in the environment, we grouped lignin-derived phenols and other-source phenols into one single group class as phenols/lignin monomers due to their chemical similarity, which makes a clear separation between both compound classes impossible. One possible explanation for the increased proportions of phenols/lignin monomers compounds is due to roots, since lignin is more abundant in roots than in shoots [61], and root biomass contributes strongly to subsoil OM [9]. However, the dominant peaks for grass roots at $m / z 194$ (ferulic acid) and 208 (sinapyl aldehyde) were observed at 0-25 cm, but absent at 25-35 cm (Figure 2 and Supplementary Materials: Figure S2). In addition, the root abundance generally decreased with soil depth based on field observations (Supplementary Materials: Table S1). Therefore, the greater percentage of lignin monomers/phenols in deeper soils in our study is unlikely due to grass roots. Instead, the greater proportion of phenols/lignin monomers in subsoil might be attributed to their enhanced stability, since Py-FIMS analysis showed that the thermal stability of clay-associated phenols/lignin monomers increased with soil depth (Figure 3). It is also interesting to note that the relative percentages of lignin dimers, the thermal stability of which showed no variations with soil depth (Figure 3e), generally decreased with depth (Table 2). Phenols/lignin monomers could be stabilized by interaction with clay minerals or $\mathrm{Fe} / \mathrm{Al}$ oxides, as aromatic and phenolic compounds have a strong affinity for oxides or aluminosilicates [62,63]. Kramer et al. [64] demonstrated the long-term accumulation of plant-derived lignin and phenolic compounds in direct association with short-range-ordered minerals. Considering the particular interest in the stability of phenolic compounds in soils, further investigation on phenolics stabilization by interactions with soil mineral phases is needed.

The pronounced differences in the vertical distribution of SOM composition between the summit and footslope soil profiles were reflected in a greater degree of increase in the percentages of 
alkylaromatics and phenols/lignin monomers with increasing soil depth in the footslope soils. SOM composition is similar in surface soils between the summit and footslope soils, which was also observed in other previous studies $[65,66]$, may predominantly reflect the uniform vegetation distribution in the surface. The larger increase in the relative abundance of alkylaromatics with soil depth in the footslope profile might be due to less input of fresh plant materials to the footslope subsurface and/or the more advanced degradation of organic compounds. In addition, the relatively greater accumulation of phenols/lignin-monomers at the poorly-drained footlsope subsoils, than the relatively well-drained summit location, suggests the likely retardation of the activity of obligate aerobic lignin-decomposing fungi and resultant selective preservation of lignin-like compounds $[35,36,67]$.

\subsection{Variation in SOM Thermal Stability with Depth and LANDSCAPE position}

In both the summit and footslope surface soils, the thermostability of clay-associated organic compounds increases in the order: carbohydrates and $\mathrm{N}$ compounds $<$ phenols + lignin monomers $<$ lignin dimers and alkylaromatics. Lignin dimers (minor fractions) and alkylaromatics in the surface soils require substantially higher temperatures $\left(430-470^{\circ} \mathrm{C}\right)$ to be volatilized and might be indicative of a thermodynamic barrier to decomposition. In contrast, the majority of clay-bound carbohydrates and $\mathrm{N}$ compounds in the surface soils were volatilized at low pyrolysis temperatures $\left(330-350{ }^{\circ} \mathrm{C}\right)$. The volatilization of clay-associated $\mathrm{OM}$ at low temperatures originates from a thermally labile factions of carbohydrates and $\mathrm{N}$ compounds with weak organic-mineral or organic-organic bonds. It was previously reported that aromatic $\mathrm{C}=\mathrm{C}$ and alkyl $\mathrm{C}-\mathrm{H}$ bonds are higher energetic molecular bonds, whereas compounds like carbohydrates and peptides require relatively low activation energies for their decomposition [22,68-70]. Our results thus suggest that the chemical characteristics of SOM remain a major driver of OM persistence in the surface soils, although the role of the chemical composition of SOM in determining its turnover has recently been questioned [1,3,4].

SOM thermostability generally increased with soil depth. The same finding was published by Purton et al. [32] who reported general increases in thermal stability of OM compound classes downward through soil profiles from $0-5$ to $15-20 \mathrm{~cm}$, irrespective of land use. By extending from assessing the thermal stability of whole soil OM to that of the individual OM compound classes associated with soil minerals at varying soil depths, our study demonstrated for the first time that the stability of clay-associated carbohydrates, N-containing compounds and phenols/lignin monomers increased with increasing soil depth, whereas thermally-stable compound classes including clay-associated alkylaromatics and lignin dimers are hardly affected by soil depth. This result suggests not all types of SOM are equally influenced by the change in environment, with the stability of more labile OM compound classes more sensitive to environmental changes. The higher thermal stability of clay-associated OM compound classes is directly indicative of stronger organic-organic or organic-mineral bonds. The enrichment of a relative stable proportion of carbohydrates, $\mathrm{N}$ compounds and phenols/lignin monomers as soil depth increases, is likely to due to the decomposition of the labile portion of these compound classes and/or resynthesized stable compounds. Changes in the chemical nature of these compound classes may result in stronger organic-organic bonds and thus increase their resistance to pyrolysis. At $25-35 \mathrm{~cm}$ in the footslope soil, the thermal stability of carbohydrates, $\mathrm{N}$ compounds and phenols/lignin monomers increased to that of alkylaromatic and lignin dimers, and thus the thermograms of all the major compound classes were similar in this soil, and all the major compound classes seem to be thermally resistant up to high temperatures (Figure 3). It is unlikely that the changes in the thermal stability of OM compound classes could be attributed to their inherent molecular proprieties alone in this soil. The enhanced thermostability may also be ascribed to the strength of the bonding between OM and minerals which increases with soil depth due to the decreases in OM loadings (Table 1). This study, thus, implies that compared to surface soils, organic-mineral associations may be more important in determining OM persistence in subsoils and could largely retard the decomposition of biochemically labile materials like carbohydrates and peptides. Compelling evidence for the binding of almost all compound classes from Py-FIMS analysis by pedogenic Fe-oxides, 
leading to thermal stabilization in particle-size fractions of a Haplaquoll soil, was published by Schulten and Leinweber [71]. An OM loading of $1 \mathrm{mg} \mathrm{C} \mathrm{m}^{-2}$ has been previously proposed as the maximum C loading [72,73]. OM loadings of the clay fractions from $0-15 \mathrm{~cm}$ were $1.1-1.2 \mathrm{mg} \mathrm{C} \mathrm{m}^{-2}$, suggesting that these surface soils may have reached $C$ saturation. In contrast, the clay fractions from $25-35 \mathrm{~cm}$ have OM loading of $0.3-0.4 \mathrm{mg} \mathrm{C} \mathrm{m}^{-2}$, which is much lower than the suggested maximum $\mathrm{C}$ loading. Kaiser and Guggenberger [25,74] discussed that potential OM stabilization at mineral surfaces is limited to those OM molecules that sorb to surfaces with small surface loading. At higher OM loadings at the mineral surface, less organic ligands per organic molecule are involved in the bonding, making the organic molecules more susceptible to decomposition. Sollins et al. [75] and Kleber et al. [76] discussed a zonal structure for $\mathrm{OM}$ associated with mineral surfaces, with the outer layers of the OM having a more rapid turnover than the inner ones. As the molecular structure of SOM is very complex and the inherent molecular nature as well as the degree of organic-mineral association often co-vary in the natural soils and sediments, it is extremely challenging to directly determine the relative importance of OM molecular properties vs. organic-mineral association in controlling SOM persistence in the natural environment. Further research including studies on synthetic systems with pure minerals and organic molecules is essential to disentangle the importance of organic-mineral associations and the intrinsic chemical nature of $\mathrm{OM}$ on the stability of organo-mineral complexes.

The thermal stability of clay-associated alkylaromatics and lignin dimers, which are already of the highest stability, did not change with soil depth. The high-temperature volatilization of lignin dimers was also observed in the heavy-density fractions of a Gleysol [77]. The uniform and similar high-temperature thermal volatilization of lignin dimers and alkylaromatics along the soil profile might be due to the fact that intrinsic chemical nature of these two compound classes is relatively homogeneously distributed and, thus, shows no variations along with soil depth. Or it might be because that the changes in organic-mineral association as a function of soil depth may not be able to affect the stability of alkylaromatics and lignin dimers, which are already highly stable and thermally resistant up to high temperatures.

\section{Conclusions}

This study indicates that subsoil OM is more microbially decomposed than surface SOM, and characterized by increasing proportions of alkylaromatics concurrent with decreasing abundance of sterols with soil depth. The relative percentages of phenols/lignin monomers increased with soil depth, probably due to their enhanced stability. In addition, the footslope soil profile showed a greater degree of increase in the phenols/lignin monomers with increasing soil depth than the summit soil profile, likely due to the selective preservation of these compound classes under poorly-drained conditions. Moreover, this study implies that the role of molecular structure versus organo-mineral associations for SOM stabilization may change with soil depth. This study suggests that in surface soils, the chemical characteristics of OM remain a major driver for OM persistence in the soils, and that this may result from specific bond energies at the molecular level. However, for subsoils, a greater degree of organic-organic binding and/or organo-mineral associations appear to increase the thermal stability of the more thermally-labile organic compound classes like carbohydrates, peptides and phenols/lignin monomers as soil depth increases. In contrast, the thermal stability of alkylaromatics and lignin dimers, which are highly stable and thermally resistant to very high temperatures, is not affect by soil depth. This study implies that organic-mineral associations might be more important in controlling the persistence of biochemically labile compounds in subsoils, compared to surface soils. In addition, we suggest that soil $C$ turnover models would benefit from viewing turnover rates of biochemically labile compounds based on the degree of their association with soil minerals (e.g., OC loading). This study may help better predicting the resilience of protected OM against disturbances caused by changes in environmental conditions and land management.

Supplementary Materials: The following are available online at www.mdpi.com/2571-8789/2/1/16/s1, Figure S1. (a) Map of Christina River Basin $\left(\sim 1440 \mathrm{~km}^{2}\right)$ (marked with black color). (b) Picture of the sampled 
pasture hillslope, Figure S2. Summed and averaged pyrolysis-field ionization mass spectra and thermograms of total ion intensity (TII, inset) of whole soils from summit at soil depth $0-15$ and $15-25 \mathrm{~cm}$, and footslope at soil depth of 0-15 and 25-35 cm, Figure S3: Pyrolysis thermograms of (a) carbohydrates, (b) heterocyclic nitrogen and nitriles, (c) amides, (d) phenols and lignin monomers, (e) lignin dimers, and (f) alkylaromatics for whole soils from summit at soil depth $0-15$ and 15-25 cm, and footslope at a soil depth of 0-15 and 25-35 cm, Table S1. General soil description, Table S2. Bulk soil properties, Table S3. Total Fe, dithionite-extractable Fe, and oxalate-extractable Fe in bulk soils, Table S4. Marker signals in Py-FIMS of soil samples, Table S5. Compound class groups of marker signals from pyrolysis-field ionization mass spectrometry of whole soils and their clay fractions from summit at soil depth $0-15$ and $15-25 \mathrm{~cm}$, and footslope at soil depth of $0-15$ and $25-35 \mathrm{~cm}$.

Acknowledgments: We thank Anthony Aufdenkampe from the Stroud Water Research Center and Kyungsoo Yoo from the University of Minnesota for their helpful discussions on this research. The research is a part of the Christina River Basin Critical Zone Observatory (CRB-CZO) project that was supported by the National Science Foundation (EAR 0724971). C XANES analysis was performed at the SM beamline of the Canadian Light Source, which is supported by the Natural Sciences and Engineering Research Council of Canada, the National Research Council of Canada, the Canadian Institutes of Health Research, the Province of Saskatchewan, Western Economic Diversification Canada, and the University of Saskatchewan.

Author Contributions: Chunmei Chen conceived, designed, and performed the experiments with support from Peter Leinweber and Kai-Uwe Eckhardt. Peter Leinweber and Kai-Uwe Eckhardt performed Py-FIMS analysis, data processing and interpretation. Chunmei Chen wrote the paper with edits from Peter Leinweber and Donald L. Sparks. Donald L. Sparks guided the overall goals of the research projects and provided research ideas. All authors read and approved the content.

Conflicts of Interest: The authors declare no conflict of interest.

\section{References}

1. Schmidt, M.W.I.; Torn, M.S.; Abiven, S.; Dittmar, T.; Guggenberger, G.; Janssens, I.V.; Kleber, M.; Kögel-knabner, I.; Lehmann, J.; Manning, D.A.C.; et al. Persistence of soil organic matter as an ecosystem property. Nature 2011, 478, 49-56. [CrossRef] [PubMed]

2. Lehmann, J.; Kleber, M. The contentious nature of soil organic matter. Nature 2015, 528, 60-68. [CrossRef] [PubMed]

3. Marschner, B.; Brodowski, S.; Dreves, A.; Gleixner, G.; Gude, A.; Grootes, P.M.; Hamer, U.; Heim, A.; Jandl, G.; Ji, R.; et al. How relevant is recalcitrance for the stabilization of organic matter in soils? J. Plant Nutr. Soil Sci. 2008, 171, 91-110. [CrossRef]

4. Kleber, M.; Nico, P.S.; Plante, A.; Filley, T.; Kramer, M.; Swanston, C.; Sollins, P. Old and stable soil organic matter is not necessarily chemically recalcitrant: Implications for modeling concepts and temperature sensitivity. Glob. Change Biol. 2011, 17, 1097-1107. [CrossRef]

5. Torn, M.S.; Trumbore, S.E.; Chadwick, O.A.; Vitousek, P.M.; Hendricks, D.M. Mineral control of soil organic carbon storage and turnover. Nature 1997, 389, 170-173. [CrossRef]

6. Błońska, E.; Lasota, J.; Gruba, P. Enzymatic activity and stabilization of organic matter in soil with different detritus inputs. J. Soil Sci. Plant Nutr. 2017, 63, 242-247.

7. Błońska, E.; Lasota, J. Soil Organic Matter Accumulation and Carbon Fractions along a Moisture Gradient of Forest Soils. Forests 2017, 8, 448. [CrossRef]

8. Chabbi, A.; Kögel-Knabner, I.; Rumpel, C. Stabilised carbon in subsoil horizons is located in spatially distinct parts of the soil profile. Soil Biol. Biochem. 2009, 41, 256-261. [CrossRef]

9. Rumpel, C.; Kögel-Knabner, I. Deep soil organic matter-A key but poorly understood component of terrestrial C cycle. Plant Soil 2011, 338, 143-158. [CrossRef]

10. Trumbore, S. Age of soil organic matter and soil respiration: Radiocarbon constraints on belowground C dynamics. Ecol. Appl. 2000, 10, 399-411. [CrossRef]

11. Jenkinson, D.S.; Poulton, P.R.; Bryant, C. The turnover of organic carbon in subsoils. Part 1. Natural and bomb radiocarbon in soil profiles from the rothamsted long-term field experiments. Eur. J. Soil Sci. 2008, 59, 391-399. [CrossRef]

12. Lomander, A.; Kätterer, T.; Andrén, O. Carbon dioxide evolution from top- and subsoil as affected by moisture and constant and fluctuating temperature. Soil Biol. Biochem. 1998, 30, 2017-2022. [CrossRef]

13. Coleman, K.; Jenkinson, D.S.; Crocker, G.J.; Grace, P.R.; Klir, J.; Körschens, P.R.; Richter, D.D. Stimulating trends in soil organic carbon in long-term experiments using Roth C-26.3. Geoderma 1997, 81, $29-44$. [CrossRef] 
14. Stevenson, F.J. Biochemistry of the formation of humic substances. In Humus Chemistry, Genesis, Composition, Reactions; Stevenson, F.J., Ed.; John Wiley \& Sons Inc.: New York, NY, USA; pp. 188-211.

15. Krull, E.S.; Skjemstad, J.O. ${ }^{13} \mathrm{C}$ and ${ }^{15} \mathrm{~N}$ profiles in ${ }^{14} \mathrm{C}$-dated oxisols and vertisols as a function of soil chemistry and mineralogy. Geoderma 2003, 112, 1-29. [CrossRef]

16. Liang, C.; Balser, T.C. Preferential sequestration of microbial carbon in subsoils of glacial landscape toposequence, Dave County, WI, USA. Geoderma 2008, 148, 113-119. [CrossRef]

17. Salomé, C.; Nunan, N.; Pouteau, V.; Lerch, T.Z.; Chenu, C. Carbon dynamics in topsoil and in subsoil may be controlled by different regulatory mechanisms. Glob. Change Biol. 2010, 16, 416-426. [CrossRef]

18. Rumpel, C.; Esterhues, K.; Kögel-Knabner, I. Non-cellulosic neutral sugar contribution to mineral associated organic matter in top- and subsoil horizons oft wo acid forest soils. Soil Biol. Biochem. 2010, 42, 379-382. [CrossRef]

19. Rumpel, C.; Rodríguez-Rodríguez, A.; González-Pérez, J.A.; Arbelo, C.; Chabbi, A.; Nunan, N.; González-Vila, F.J. Contrasting composition of free and mineral-bound organic matter in top- and subsoil horizons of Andosols. Biol. Fertil. Soils 2012, 48, 401-411. [CrossRef]

20. Gill, R.A.; Burke, I.C. Influence of soil depth on the decomposition of Bouteloua gracilis roots in the shortgrass steppe. Plant Soil 2002, 241, 233-242. [CrossRef]

21. Taylor, J.P.; Wilson, B.; Mills, M.S.; Burns, R.G. Comparison of microbial numbers and enzymatic activities in surface soils and subsoils using various techniques. Soil Biol. Biochem. 2002, 34, 387-401. [CrossRef]

22. Davidson, E.A.; Janssens, I.A. Temperature sensitivity of soil carbon decomposition and feedbacks to climate change. Nature 2006, 440, 165-173. [CrossRef] [PubMed]

23. Hagerty, S.B.; van Groenigen, K.J.; Allison, S.D.; Hungate, B.A.; Schwartz, E.; Koch, G.W.; Kolka, R.K.; Dijkstra, P. Accelerated microbial turnover but constant growth efficiency with warming in soil. Nat. Clim. Chang. 2014, 4, 903-906. [CrossRef]

24. Mobley, M.L.; Lajtha, K.; Kramer, M.G.; Bacon, A.R.; Heine, P.R.; Richter, D.D. Surficial gains and subsoil losses of soil carbon and nitrogen during secondary forest development. Glob. Change Biol. 2015, 21, 986-996. [CrossRef] [PubMed]

25. Kaiser, K.; Guggenberger, G. Mineral surfaces and soil organic matter. Eur. J. Soil Sci. 2003, 54, $219-236$. [CrossRef]

26. Eusterhues, K.; Rumpel, C.; Kögel-Knabner, I. Organo-mineral associations in sandy acid forest soils: Importance of specific surface area, iron oxides and micropores. Eur. J. Soil Sci. 2005, 56, 753-763. [CrossRef]

27. Eusterhues, K.; Rumpel, C.; Kögel-Knabner, I. Stabilization of soil organic matter isolated by oxidative degradation. Org. Geochem. 2005, 36, 1567-1575. [CrossRef]

28. Viaud, V.; Angers, D.; Walter, C. Toward landscape-scale modeling of soil organic matter dynamics in agroecosystems. Soil Sci. Soc. Am. J. 2010, 74, 1847-1860. [CrossRef]

29. Anderson, J.M. The effects of climate change on decomposition processes in grasslands and coniferous forests. Ecol. Appl. 1991, 1, 326-347. [CrossRef] [PubMed]

30. White, R.P.; Murray, S.; Rohweder, M. Pilot Analysis of Global Ecosystems: Grassland Ecosystems; World Resources Institute: Washington, DC, USA, 2000.

31. Feng, X.; Simpson, M.J. The distribution and degradation of biomarkers in Albeta grassland soil profiles. Org. Geochem. 2007, 38, 1558-1570. [CrossRef]

32. Purton, K.; Walley, F.; Pennock, D.; Leinweber, P. Will climate change and associated land use shifts affect soil organic matter composition? Evidence from an ecotonic climosequence. Geoderma 2015, 253-254, 48-60. [CrossRef]

33. Rumpel, C.; Kögel-Knabner, I.; Bruhn, F. Vertical distribution, age, and chemical composition of organic carbon in two forest soils of different pedogenesis. Org. Geochem. 2002, 33, 1131-1142. [CrossRef]

34. Mason, S.L.; Filley, T.R.; Abbott, G.D. The effect of afforestation on the soil organic carbon (SOC) of a peaty gley soil using on-line thermally assisted hydrolysis and methylation (THM) in the presence of 13C-labelled tetramethylammonium hydroxide (TMAH). J. Anal. Appl. Pyrolysis 2009, 85, 417-425. [CrossRef]

35. Williams, C.J.; Yavitt, J.B. Botanical composition of peat and degree of peat decomposition in three temperate peatlands. Ecoscience 2003, 10, 85-95. [CrossRef]

36. Thevenot, M.; Dignac, M.F.; Rumpel, C. Fate of lignins in soils: A review. Soil Biol. Biochem. 2010, 42, 1200-1211. [CrossRef] 
37. Schulten, H.R.; Leinweber, P. New insights into organic-mineral particles: Composition, properties and models of molecular structure. Biol. Fertil. Soils 2000, 30, 399-402. [CrossRef]

38. Chen, C.; Dynes, J.; Wang, J.; Karunakaran, C.; Sparks, D.L. Soft x-ray spectromicroscopy study of mineral-organic matter associations in pasture soil clay fractions. Environ. Sci. Technol. 2014, 48, 6678-6686. [CrossRef] [PubMed]

39. Newbold, J.D.; Bott, R.L.; Kaplan, L.A.; Sweeney, B.W.; Vannote, R.L. Organic matter dynamics in White Clay Creek, Pennsylvania, USA. J. N. Am. Benthol. Soc. 1997, 6, 46-50. [CrossRef]

40. Sloto, R.A. Geology, Hydrology, and Ground Water Quality of Chester County, Pennsylvania; Chester County Water Resources Authority Water-Resource Report 2; Chester County Water Resources Authority: Chester, PA, USA, 1994.

41. Amelung, W.; Zech, W.; Zhang, X.; Follett, R.F.; Tiessen, H.; Knox, E.; Flach, K.W. Carbon, nitrogen, and sulfur pools in particle-size fractions as influenced by climate. Soil Sci. Soc. Am. J. 1998, 62, 171-181. [CrossRef]

42. Mehra, O.P.; Jackson, M.L. Iron oxide removal from soils and clays by a dithionite-citrate system buffered with sodium bicarbonate. Clays Clay Miner. 1960, 7, 317-327. [CrossRef]

43. Burt, R. Soil Survey Laboratory Methods Manual; Soil Survey Investigations Report No. 42 Version 4.0; Natural Resources Conservation Service, U.S. Department of Agriculture: Lincoln, NE, USA, 2004.

44. Brunauer, S.; Emmett, P.H.; Teller, E. Adsorption of gases in multimolecular layers. J. Am. Chem. Soc. 1938, 160, 309-319. [CrossRef]

45. Regier, T.; Krochak, J.; Sham, T.K.; Hu, Y.F.; Thompson, J.; Blyth, R.I.R. Performance and capabilities of the Canadian Dragon: The SGM beamline at the Canadian Light Source. Nucl. Instrum. Meth. A 2007, 582, $93-95$. [CrossRef]

46. Chen, C.; Sparks, D.L. Multi-elemental scanning transmission X-ray microscopy-near edge X-ray absorption fine structure spectroscopy assessment of organo-mineral associations in soils from reduced environments. Environ. Chem. 2015, 12, 64-73. [CrossRef]

47. Wan, J.M.; Tyliszczak, T.; Tokunaga, T.K. Organic carbon distribution, speciation, and elemental correlations with soil micro aggregates: Applications of STXM and NEXAFS spectroscopy. Geochim. Cosmochim. Acta 2007, 71, 5439-5449. [CrossRef]

48. Lehmann, J.; Solomon, D.; Kinyang, J.; Dathe, L.; Wirick, S.; Jacobsen, S. Spatial complexity of soil organic matter forms at nanometer scales. Nat. Geosci. 2008, 1, 238-242. [CrossRef]

49. Leinweber, P.; Jandl, G.; Eckhardt, K.U.; Schlichting, A.; Hofmann, D.; Schulten, H.R. Analytical pyrolysis and soft-ionization mass spectrometry. In Biophysico-Chemical Processes Involving Natural Nonliving Organic Matter in Environmental Systems; Senesi, N., Xing, B., Huang, P.M., Eds.; John Wiley \& Sons: New York, NY, USA, 2009; pp. 533-582.

50. Leinweber, P.; Kruse, J.; Baum, C.; Arcand, M.; Knight, J.D.; Farrell, R.; Eckhardt, K.U.; Kiersch, K.; Jandi, G. Advances in understanding organic nitrogen chemistry in soils using state-of-the-art analytical techniques. Adv. Agron. 2013, 119, 83-151.

51. Kalbitz, K.; Schmerwitz, J.; Schwesig, D.; Matzner, E. Biodegradation of soil-derived dissolved organic matter as related to its properties. Geoderma 2003, 113, 273-291. [CrossRef]

52. Ussiri, D.A.N.; Johnson, C.E. Characterization of organic matter in a northern hardwood forest soil by ${ }^{13}$ C NMR spectroscopy and chemical methods. Geoderma 2003, 111, 123-149. [CrossRef]

53. Rumpel, C.; Eusterhues, K.; Kögel-Knabner, I. Location and chemical composition of stabilized organic carbon in topsoil and subsoil horizons of two acid forest soils. Soil Biol. Biochem. 2004, 36, 177-190. [CrossRef]

54. Djukic, I.; Zehetner, F.; Tatzber, M.; Gerzabek, M.H. Soil organic-matter stocks and characteristics along an Alpine elevation gradient. J. Plant Nutr. Soil Sci. 2010, 173, 30-38. [CrossRef]

55. Leinweber, P.; Eckhardt, K.U.; Fischer, H.; Kuzyakov, K. A new rapid micro-method for the molecular-chemical characterization of rhizodeposits by field-ionization mass spectrometry. Rapid Commun. Mass Spectrom. 2008, 22, 1230-1234. [CrossRef] [PubMed]

56. Sleutel, S.; Leinweber, P.; Ara Begum, S.; Kader, M.A.; Van Oostveldt, P.; De Neve, S. Composition of organic matter in sandy relict and cultivated heathlands as examined by Pyrolysis-Field Ionization MS. Biogeochemistry 2008, 89, 253-271. [CrossRef]

57. Gillespie, A.; Walley, F.; Farrell, R.; Leinweber, P.; Eckhardt, K.U.; Regier, T.; Blyth, R. XANES and Pyrolysis-FIMS evidence of organic matter composition in a hummocky landscape. Soil Sci. Soc. Am. J. 2011, 75, 1741-1755. [CrossRef] 
58. Sleutel, S.; Kader, M.A.; Leinweber, P.; D’Haene, K.; De Neve, S. Tillage management alters surface soil organic matter composition: A pyrolysis mass spectroscopy study. Soil Sci. Soc. Am. J. 2007, 71, 1620-1628. [CrossRef]

59. Millard, P. Ecophysiology of the internal cycling of nitrogen for tree growth. Z. Pflanzenernahr. Bodenkd. 1996, 159, 1-10. [CrossRef]

60. Sanger, L.M.; Anderson, J.M.; Little, D.; Bolger, T. Phenolic and carbohydrate signatures of organic matter in soils developed under grass and forest plantations following changes in land use. Eur. J. Soil. Sci. 1997, 48, 311-317. [CrossRef]

61. Rasse, D.P.; Rumpel, C.; Dignac, M.F. Is soil carbon mostly root carbon? Mechanisms for a specific stabilisation. Plant Soil 2005, 269, 341-356. [CrossRef]

62. Riedel, T.; Zak, D.; Biester, H.; Dittmar, T. Iron traps terrestrially derived dissolved organic matter at redox interfaces. Proc. Natl. Acad. Sci. USA 2013, 110, 10101-10105. [CrossRef] [PubMed]

63. Wang, Y.Y.; Wang, H.; He, J.S.; Feng, X.J. Iron-mediated soil carbon response to water-table decline in an alpine wetland. Nat. Commun. 2017, 8, 15972. [CrossRef] [PubMed]

64. Kramer, M.G.; Sanderman, J.; Chadwick, O.A.; Chorover, J.; Vitousek, P.M. Long-term carbon storage through retention of dissolved aromatic acids by reactive particles in soil. Glob. Chang. Biol. 2012, 18, 2594-2605. [CrossRef]

65. Berhe, A.A.; Harden, J.W.; Torn, M.S.; Kleber, M.; Burton, S.D.; Harte, J. Persistence of soil organic matter in eroding versus depositional landform positions. J. Geophys. Res. Biogeosci. 2012, 117, G02019. [CrossRef]

66. Wang, X.; Cammeraat, E.L.H.; Cerli, C.; Kalbitz, K. Soil aggregation and the stabilization of organic carbon as affected by erosion and deposition. Soil Biol. Biochem. 2014, 72, 55-65. [CrossRef]

67. Opsahl, S.; Benner, R. Early diagenesis of vascular plant tissues: Lignin and cutin decomposition and biogeochemical implications. Geochim. Cosmochim. Acta 1995, 59, 4889-4904. [CrossRef]

68. LaRowe, D.E.; Van Cappellen, P. Degradation of natural organic matter: A thermodynamic analysis. Geochim. Cosmochim. Acta 2011, 75, 2030-2042. [CrossRef]

69. Haider, K.; Martin, J.P. Decomposition of specifically carbon-14 labeled benzoic and cinnamic acid derivatives in soil. Soil Sci. Soc. Am. J. 1975, 39, 657-662. [CrossRef]

70. Hedges, J.I.; Cowie, G.L.; Erte, J.R.; Barbour, R.J.; Hatcher, P.G. Degradation of carbohydrates and lignins in buried woods. Geochim. Cosmochim. Acta 1985, 49, 701-711. [CrossRef]

71. Schulten, H.R.; Leinweber, P. Dithionite-citrate-bicarbonate-extractable organic matter in particle-size fractions of a Haplaquoll. Soil Sci. Soc. Am. J. 1995, 59, 1019-1027. [CrossRef]

72. Feng, W.; Plante, A.F.; Six, J. Improving estimates of maximal organic carbon stabilization by fine soil particles. Biogeochemistry 2013, 112, 81-93. [CrossRef]

73. Mayer, L.M. Relationships between mineral surfaces and organic carbon concentrations in soils and sediments. Chem. Geol. 1994, 114, 347-363. [CrossRef]

74. Kaiser, K.; Guggenberger, G. Sorptive stabilization of organic matter by microporous goethite: Sorption into small pores vs. surface complexation. Eur. J. Soil Sci. 2007, 58, 45-59. [CrossRef]

75. Sollins, P.; Swanston, C.; Kleber, M.; Filley, T.; Kramer, M.G.; Crow, S.E.; Caldwell, B.; Lajtha, K.; Bowden, R. Organic $\mathrm{C}$ and $\mathrm{N}$ stabilization in a forest soil: Evidence from sequential density fractionation. Soil Biol. Biochem. 2006, 38, 3313-3324. [CrossRef]

76. Kleber, M.; Sollins, P.; Sutton, R. A conceptual model of organo-mineral interactions in soils: Self-assembly of organic molecular fragments into zonal structures of mineral surfaces. Biogeochemistry 2007, 85, 9-24. [CrossRef]

77. Schulten, H.R.; Leinweber, P. Thermal stability and composition of mineral-bound organic matter in density fractions of soil. Eur. J. Soil Sci. 1999, 50, 237-248. [CrossRef]

(C) 2018 by the authors. Licensee MDPI, Basel, Switzerland. This article is an open access article distributed under the terms and conditions of the Creative Commons Attribution (CC BY) license (http:/ / creativecommons.org/licenses/by/4.0/). 